Brian C. Macallan*

\title{
Getting off the Omnibus: Rejecting Free Will and Soul-Making Responses to the Problem of Evil
}

https://doi.org/10.1515/opth-2020-0005

Received October 26, 2019; accepted December 06, 2019

\begin{abstract}
The nature of suffering and the problem of evil have been perennial issues for many of the world's religious traditions. Each in their own way has sought to address this problem, whether driven by the all too present reality of suffering or from philosophical and religious curiosities. The Christian tradition has offered numerous and diverse responses to the problem of evil. The free-will response to the problem of evil, with its roots in Augustine, has dominated the landscape in its attempt to justify evil and suffering as a result of the greater good of having free will. John Hick offers a 'soul-making' response to the problem of evil as an alternative to the free will response. Neither is effective in dealing with two key issues that underpin both responses - omnipotence and omniscience. In what follows I will contrast a process theological response to the problem of evil and suffering, and how it is better placed in dealing with both omnipotence and omniscience. By refashioning God as neither all-knowing nor all-powerful, process theodicy moves beyond the dead ends of both the free will and soul-making theodicy. Indeed, a process theodicy enables us to dismount the omnibus in search of a more holistic, and realistic, alternative to dealing with the problem of evil and suffering.
\end{abstract}

Keywords: Process Theology, omnipotence, omniscience, Hick, suffering

\section{Introduction}

The problem of evil, or the problem of evil in relation to God (theodicy), takes place against the background of the reality and all too apparent suffering that has been synonymous with human life from time immemorial. Evil might be too strong a word to explain what happened to creatures in evolutionary history, but the notion of suffering and pain would not be. It's impossible to know at what point homo sapiens began to worship Gods, let alone when they began to question their suffering and how it is related to the nature and reality of God. It appears that even our cousins homo neanderthalensis had certain burial rites for their dead, but that's as much as we know.

Different religions approach the question of suffering and evil uniquely. As one who has found myself broadly within the Christian tradition, I have been informed by the questions and answers that have been put forward within that stream for understanding theodicy. As will become apparent as this article progresses, even the Christian tradition has had numerous and quite different reflections on these problems. Debates around the nature of suffering and pain are routinely construed as academic and abstract, unrelated to real physical and existential suffering, and this can certainly be the case.

*Corresponding author: Brian C. Macallan, University of Divinity, Stirling Theological College, Melbourne, Australia;

E-mail: briancmacallan@gmail.com

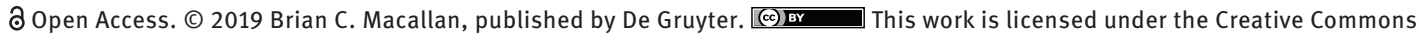
Attribution 4.0 Public License. 
C.S. Lewis wrote what was considered an abstract approach to the problem of suffering in his book The Problem of Pain. ${ }^{1}$ It was only when his partner Joy developed cancer, and subsequently died, that his abstract thoughts became grounded in reality, followed up by his book A Grief Observed. ${ }^{2}$ It is easy to criticize Lewis for his former work, and for being out of touch when he referred to pain as "God's megaphone to the world". I too held rather abstract beliefs regarding free will and the nature of suffering before experiencing the illness of a child, along with being diagnosed with colon cancer at a young age. ${ }^{3}$ My journey required, and led to, a reappraisal regarding the question of theodicy. It is against this background that the engagement with John Hick's theodicy takes place. In some ways, the essay mimics my theodicy journey from a free-will position, through John Hick's soul-making theodicy, to a process and open theological perspective. After critiquing both the free will and soul-making theodicies I will offer the process perspective as a more coherent and suitable option for making sense of evil and suffering. Indeed, it offers us a way of getting off what I call the omnibus, or traditional conceptions of omnipotence and omniscience.

\section{The Problem of Evil Classically Formed and Its Problems}

Is he willing to prevent evil, but not able? Then is he impotent. Is he able, but not willing? Then is he malevolent. Is he both able and willing? Whence then is evil? - David Hume

The above quote by the philosopher David Hume outlines the problem of evil that both theologians and philosophers of religion have wrestled with for centuries. ${ }^{4}$ In its very formulation however, it demonstrates a highly Western conception of the problem of evil, as well as one that seems locked in Greek metaphysical thinking. It is in response to this very question that Hume asks us to consider, that both free will and soulmaking responses have sought to address their responses. The first response is the free will, or what is also traditionally known as an Augustinian response, while the second being the soul-making ${ }^{5}$, or a person making Irenean theodicy option. Both approaches further maintain metaphysical assumptions regarding omnipotence and omniscience that result in them running into significant difficulties in understanding the purpose and nature of suffering. A process theodicy seems better placed to deal with the challenge of Hume's question, along with some of the problems in both the free will and soul-making theodicies. A process theodicy in fact challenges core assumptions in David Hume's question itself that invalidate the very structure of his argument. This is because a process theodicy rejects both omnipotence and certain aspects of omniscience that negates the "able to" aspect of Hume's question. It further rejects the implication that God is therefore impotent if God is not omnipotent. A process conception of power is one that rethinks power as persuasive and not coercive. ${ }^{6}$

To demonstrate this, I will begin by outlining briefly the free will response and its central concern. I will then look at Hick and his rejection of the free-will response to the problem of evil, and his alternative soulmaking theodicy. Both approaches will be critiqued as inadequate in dealing with the reality and problem of suffering. The core features of a process theodicy will then be articulated with specific reference to how they address deficiencies in both the free will and soul-making responses. This will illustrate the problem in the very framing of Hume's question regarding God and omnipotence. Mackie has suggested that this

1 Lewis, The problem of pain.

2 Lewis, A grief observed.

3 In 2013 at the age of thirty-five I was diagnosed with colon cancer. After an operation and chemotherapy I am in remission currently.

4 Hume, Dialogues concerning natural religion, 63.

5 Although the term soul-making theodicy is still common, Hick later in life preferred the term 'person making' instead of 'soul-making'. From this point on I will use the term 'person making'.

6 To persuade within a process understanding is the opposite of using force to achieve a specific outcome (coercive). God rather lures us towards a preferred outcome, or as I prefer to describe this, invites us through persuasion towards a more just and whole outcome. 
(Hume's structuring of the problem of theodicy) is a problem only for those that hold to an omnipotent God. ${ }^{7}$ Therefore, the process approach I will be proposing will require us getting off the "omnibus" as mentioned earlier, represented by concepts such as omnipotence and omniscience.

\section{The Free Will Tradition}

Although the free will response has a long and rich tradition, it is Augustine who has been credited with forming the initial free-will response to the problem of evil. His understanding of evil is caught between two worlds, both Greek metaphysics and the unfolding Christian story. The Greek influence is seen in his articulation of evil as the privation of good, being heavily influenced by neo-platonic thought. ${ }^{8}$ The core of his response to the problem of evil though is rather a historical one influenced by the apostle Paul in the New Testament. The theological backdrop here is one in which God has created human beings as perfect free creatures in an original paradise. Humans then abuse their freedom and "fall" into sin with its resulting natural and moral evil. ${ }^{9}$ Hence the responsibility for evil lies in the hands of that first human couple. This tradition emphasizes the free will that the first couple had, and its importance and overarching value in and of itself. Many would not adhere to the above narrative that flows from Paul, through Augustine, and into the western tradition.

Many philosophers and theologians have however taken the general idea of free will as a legitimate defense and explanation for the problem of evil. ${ }^{10}$ The argument is made that God desires free creatures, free creatures are created, and therefore it is the free creatures that bring evil into the world. For the possibility of evil not to enter the world, God would have to have created creatures that would always do right, thereby undermining free will. Free will is seen in this tradition as so important that it overrides the potential negative impact of evil. This tradition then holds that God is still omnipotent and good, rejecting Hume's accusation. God desires evil to be eradicated but will not override the creature's free will. Evil then is ultimately not Gods responsibility (he is good), but rather the result of the misuse of free will by created creatures.

\section{Soul Making Theodicy}

Hick's Irenean theodicy notes the serious difficulties within this tradition. ${ }^{11}$ Taking evolutionary history and modern science into consideration, he dismisses all talk of perfect free creatures who have fallen from some original state and thereby introduced natural and moral evil into the world. ${ }^{12} \mathrm{He}$ is consistent though with the implications of this, by noting that taking into account evolutionary history, and the fact that God has allowed free will, makes God responsible for evil in an ultimate sense. ${ }^{13}$ The obvious question then is to why a good and omnipotent God would allow evil? Hick suggests that God's greater desire is for the formation of souls, or persons. Hick describes this position in the following way

Instead of regarding man as having been created by God in a finished state, as a finitely perfect being fulfilling the divine intention for our human level of existence, and then falling disastrously away from this, the minority report sees man as still in a process of creation...And so man, created as a personal being in the image of God, is only the raw material for a further and more difficult stage of God's creative work. This is the leading of men as relatively free and autonomous persons, through their dealings with life in the world which He has placed them. Towards that quality of personal existence that is the finite likeness of God. ${ }^{14}$

7 Mackie, "Evil and omnipotence”, 200-212.

8 Augustine, "Evil as the Privation of Good", 278-279.

9 Augustine, City of God, 271-274.

10 Van Inwagen, “The Problem of Evil”.

11 Hick, Evil and the love of God.

12 Ibid., 283-289.

13 Ibid., 326.

14 Ibid., 295. 
Hence his theodicy has come to be known as soul-making, or person making theodicy as we mentioned. The general idea is that God allows both natural and moral evil into the world for persons to be formed into moral creatures responding to their environment. Creating free creatures allows them to move towards perfection, and to do so freely. In his initial articulation of this person making theodicy, Hick argued that this person making would be completed in some form of the afterlife. ${ }^{15}$ Towards the end of this life though, he leaned strongly towards reincarnation as the process whereby this person making would be made complete. ${ }^{16}$ Hick believed that ultimately evil could only be justified with an eschatological outlook, by noting that there is no theodicy without eschatology. ${ }^{17}$ This remained important for him in his person making theodicy as suffering was often so enormous, and if God is ultimately responsible for this suffering, there must be some recompense for this in a future life. He always did maintain though that he battled to understand the amount and severity of evil in the world, leaving it to mystery. ${ }^{18}$ Hick strongly maintained that this God was both Good and Omnipotent. He believed however that God so desired free persons that it justified allowing suffering and evil into the world, being the very mechanism that God uses to bring about "persons".

Hick's person making theodicy deals quite decisively with some of the shortcomings of the free-will tradition. By taking into consideration a scientific account of the world, it highlights that natural evil was around long before hominids even arrived on the scene. This evolutionary journey of survival of the fittest also seems to be the mechanism by which life evolves, and has the potential to explain some aspects of moral evil. It does place responsibility for evil ultimately with God though, but justifies this in the greater good achieved in the formation of persons.

Hick's theodicy runs into at least two obvious difficulties though. First, concerning the amount of suffering and pain in the world and the attempt to try and justify this. Second, relating to the need to hold onto conceptions of God that see omnipotence as a key marker in delineating the nature of ultimate reality.

\section{Problems with the Free Will and Soul-Making Theodicies}

Both the free will defense, and the soul-making theodicy, hold out that there are good reasons for the fact of evil. In the case of the free will defense, it is free will itself as a goal or greater good. In the case of the person making theodicy, it is the development of a free moral person and agent. The free will theodicy sees the ultimate responsibility for evil lying with human beings, the person making theodicy sees it ultimately lying with God. Trakakis goes beyond these arguments by suggesting that there no good moral reasons for God allowing his creatures to suffer for some greater good. ${ }^{19}$ McCord Adams also notes the real difficulty with holding out some 'greater good' for suffering in general. ${ }^{20}$ She posits a specific recompense, for the specific individuals who might undergo suffering that many would deem just too horrible. It is at just this point of attempted justification, even in that proposed by McCord Adams, that Ivan Karamazov in The Brothers Karamazov challenges his brother Alyosha

Tell me yourself directly, I challenge you - reply: imagine that you yourself are erecting the edifice of human fortune with the goal of, at the finale, making people happy, of at last giving them peace and quiet, but that in order to do it it would be necessary and unavoidable to torture to death only one tiny little first, and on its avenged tears to found that edifice, would you agree to be the architect on those conditions, tell me and tell me truly. ${ }^{21}$

Ivan essentially asks whether it is worth torturing or hurting one child so that others can experience some benefit. It is here that Trakakis asks the relevant question, "what would we expect this God to say of

15 Ibid., 398-400.

16 Hick, Between Faith and Doubt: Dialogues on Religion and Reason, 157.

17 Hick, “Transcendence and truth”, 48.

18 Hick, Evil and the Love of God, 369-370.

19 Trakakis, “Theodicy: The solution to the Problem of Evil, or Part of theProblem?”, 161-191.

20 McCord Adams, Horrendous Evils and the Goodness of God.

21 Dostoyevsky, The Brothers Karamazov, 320-321. 
himself?"22 His argument is complex, but Trakakis argues that there is no morally sufficient reason to justify certain suffering, whether it is child abuse or Auschwitz. ${ }^{23}$ As against McCord Adams, he further argues that not even compensation for the individual sufferer is morally coherent. Child abuse is wrong period, regardless of future compensation. Trakakis quotes Surin in noting that we ought not to accept this price of suffering (regardless of the form of compensation), and that we ought not to be loved by such a God. ${ }^{24}$ This is one of the steps in Camus's metaphysical revolt against God where we, like Alyosha, still accept God but reject his world. ${ }^{25}$ For Camus,

The metaphysical rebel is, therefore, certainly not an atheist, as one might think him, but inevitably he is a blasphemer. He simply blasphemes, primarily in the name of order, by denouncing God as the origin of death and as the supreme disillusionment.

Ellie Weisel, in the face of the enormous suffering of children he witnessed in Birkenau concentration camp, had the same experience of having his concept of God "murdered", but not his belief in God. ${ }^{26}$ Following from this, could Trakakis not be pointing in the right direction when speaking of God's need to repent?27

If evil is morally objectionable, even for some good end, it does not necessarily lead to believing that God does not exist. Rather, it challenges us to think about the kind of God that might exist. Rowe's evidential argument from the problem of evil is powerful in refuting the belief in an omnipotent, omniscient and perfect being, or God. ${ }^{28}$ Both his premises though deal with a specific kind of God, not necessarily any kind of God. This brings us back to Trakakis's question around the kind of God that would permit such evil. ${ }^{29}$ Against Inwagen ${ }^{30}$ and Swinburne ${ }^{31}$, it is not necessarily a non-negotiable that God must be omnipotent and morally perfect. Are there not other options in the offing? Inwagen himself alters the traditional understanding of omniscience, allowing God to know all that is present but not all that is to come. ${ }^{32}$ As eastern religions begin to make their impact on the philosophy of religion, different conceptions of God and ultimate reality might have much to offer the traditional problem of evil. Much of western theodicy speaks of a God creating a world, leading to the inevitable question as to why this kind of world. Matilal argues that Sankara's move to the affirmation that the world has no beginning, and therefore God essentially has no choice, is one such proposal. ${ }^{33}$ Kaufman cautions us though, in that many eastern theodicies have not been subjected to the same scrutiny that western versions have. ${ }^{34}$ He notes some serious moral problems with the doctrine of Karma, which seems at first blush to deal nicely with the explanation of suffering. Here evil is due to transgressions in past lives, and yet we still have the ability to correct for our future lives to come. The most obvious problem with the notion of karma is an infinite regress. Who did the first wrong if the universe had no beginning? It is Hans Jonas that perhaps can point a way forward for us here. He asks penetratingly with regard to our purposes as to, "what is the matter with God that he would allow Auschwitz to happen?" 35 We have already noted there are no good moral reasons for this. ${ }^{36}$ Perhaps the hint of the answer is in the kind of God Jonas critiqued, whereby "Only a completely unintelligible God can be said to be absolutely good and absolutely powerful, yet tolerate the world as it is" ${ }^{37}$.

22 Trakakis, Theodicy, 169.

23 Ibid., 189.

24 Ibid., 181.

25 Camus, The Rebel, 50.

26 Weisel, Night, 53.

27 Trakakis, Theodicy, 169.

28 Rowe, “The evidential problem of evil”, 98-110.

29 Trakakis, Theodicy, 169.

30 Inwagen, "The problem of evil", 5.

31 Swinburne, God, 53.

32 Inwagen, “The problem of evil”, 13-14.

33 Malital, "Samkara's theodicy”, 363-376.

34 Kaufman, “Karma, Rebirth, and the Problem of Evil”, 15-16.

35 Jonas, God after Auschwitz, 1.

36 Trakakis, “Theodicy”, 161-191.

37 Jonas, God after Auschwitz, 5. 
This brings us back to Hume's point around whether God can be good and all-powerful, and yet still allow evil $^{38}$. By rejecting omnipotence and omniscience, one can also begin to understand some of the evils in this world. If God divests himself of his power to create the universe and embody it, then God truly risks and subjects God-self to becoming. ${ }^{39}$ Again, Eastern conceptions of a God who is both material and efficient cause of the universe can perhaps help us understand a God who is embodied in the world. This can begin to help us think differently about what kind of being would allow evil.

Hartshorne has noted that no worse falsehood was ever perpetrated than that of the doctrine of omnipotence. ${ }^{40}$ In light of the challenge to theodicy in general, ${ }^{41}$ and the specific moral challenge that suffering cannot be morally justified ${ }^{42}$, we are left with few options. None allow us to embrace an omnipotent and omniscient God though. A being that at some point risked creating, thereby limiting its power, while at the same time being largely unknowing to the vast amount of suffering to come, is just one such option..$^{43}$ In a traditional sense then, this God is ultimately responsible for evil still, but not in the same callous way that he would be if he were omnipotent and omniscient. Much like holding Einstein responsible for Hiroshima because of his work on splitting the atom could be justified. Whether such a being exists is of course another matter altogether. Atheistic conceptions of Rowe's ${ }^{44}$ I think are still logically valid. Eastern conceptions remove some difficulties but create others. Dualism absolves at least some aspect of the deity, or one of the deities, from responsibility. Yet the free will defense, along with the person making theodicy, has surely come upon hard times. Their God runs the risk of being downright dangerous (if being omnipotent and not good), or morally incoherent (being good and omnipotent). Either way, omnipotence must be collapsed in order to make some sense of the problem of evil.

\section{Process Theodicy as an Alternative to the Free Will and Soul-Making Options}

It is here that process theodicies have come to offer one alternative that rejects omnipotence and omniscience traditionally conceived. Evans believes that process theology resolves some of the problems of evil in the world by at times limiting God's power, his goodness, or both. ${ }^{45}$ Notably, he cautions that it is a major modification of traditional theism. Like Evans, Hick also rejects Process thought, particularly in his earlier works, because it is potentially so different from Christian faith and belief. ${ }^{46}$

Griffin has argued though, that traditional Theism's assertion that God has allowed suffering is so problematic when fused with the idea of divine foreknowledge and power, that it must be rethought. ${ }^{47}$ If God knew that this world would have the degree of suffering it does, why did he not choose a better possible world? This raises the question of whether both omnipotence and omniscience need to be rejected in favor of a process theodicy.

Process theodicies are superior to free will and soul-making responses in several ways. A central feature of process theology is its emphasis that God's power is one that persuades but does not coerce. ${ }^{48}$ Hence, in response to the free will defense, there is no "limiting" of God's intervention to allow for freedom, but

38 It was the vast amount of suffering in the world that led Carl Jung to argue for a more dualistic account of the universe (Dunne, Carl Jung). He (Jung, Answer to Job) proposes that God contains both Good and evil, a form of Manichaeistic dualism. It was this dualism that had initially won Augustine and was to make him so nervous after his conversion to Christianity. This (dualism) also solves the problem of evil by collapsing the 'good' aspect of one of Hume's premises.

39 Jonas, God after Auschwitz, 5.

40 Hartshorne, Omnipotence and other theological mistakes, 18.

41 Hume, Dialogues concerning natural religion, 1998.

42 Trakakis, “Theodicy”, 161-191.

43 Jonas, God after Auschwitz, 5.

44 Rowe, "The evidential problem of evil", 98-110.

45 Evans, Philosophy of Religion, 133.

46 Hick, Evil and the Love of God.

47 Griffin, Evil Revisited, 81-83.

48 Dombrowski, Whitehead's religious thought. 
neither is there an intentional soul-making process for creatures to become more like God. By emphasizing the fact that God did not create the world out of nothing, but rather worked with what was in existence eternally, there is no accusation of God having had to create a better world. Catherine Keller has discussed this extensively in her rejection of the traditional doctrinal formation of creation ex nihilo. ${ }^{49}$ Keller offers a process vision of God whereby God lures out of the deep, which she describes as a Novo-creation-exProfundis. Keller argues that there was no omnipotent act that brought the universe into existence. She is here drawing on the key process perspective that there have always been other entities in existence alongside God. ${ }^{50}$

God can only persuade and work with what God has. God, therefore, is unable to intervene to bring about God's desired future. God can only lure towards a better future, one in which God cannot control. For process theism,

revises our understanding of divine power. Classically, God's power is seen in terms of omnipotence, and God is creator as the sole primary efficient cause of the world. In process theism God is primarily persuasive, creating more indirectly by providing the lure for each occasion whereby it can create itself. ${ }^{51}$

It is not that freedom is something that God allows, but rather that freedom just is. Contrary to this, Omnipotence allows God to be all-powerful, but God chooses to limit his power for free will to emerge. This is deeply problematic as has already been discussed. Omnipotence in the soul-making sense, although at first blush appearing superior to the free will defense, seems to make the universe into a giant torture chamber to achieve a specific goal. Again, as noted earlier, this raises deeply troubling issues. Process theodicies are able to sidestep this by doing away with omnipotence all together. Getting off the omnibus further requires us to reject God's divine foreknowledge of future events. Cobb and Griffin note that:

In each moment of God's life there are new, unforeseen happenings in the world which only then have become knowable. Hence, God's concrete knowledge is dependent upon the decisions made by the worldly actualities. God's knowledge is always relativized by, in the sense of internally related to, the world.

This absolves God to some extent from direct responsibility for certain evil events, as even God is surprised by events that unfold. This refashioning of omniscience and omnipotence from a process perspective deals with the problem of evil in a way that neither the free will, or soul-making response to the problem of evil, can.

\section{Conclusion}

The free will and soul-making responses to the problem of evil provide different, yet in some manner not too dissimilar ways, of dealing with the problem of evil. The free will response prizes free will as of such significance that evil is allowed and permitted by God regardless of the potential cost. Hick noted the radical difficulties with this position, particularly forms of the free will response that don't allow for the reality of evolution. In his proposal of a people-making response, God creates a world where people are potentially formed towards the likeness with God. We noted the insufficiency of this proposal by highlighting that, with both the free will and Hick's person-making response, an omnipotent God essentially endorses suffering towards some greater good. Camus and Dostoyevsky raise the specter of this kind of God as deeply troubling. A process theodicy deals with the problems of both the free will and soul-making response by its rejection of omnipotence and omniscience. God would never allow or willingly condone suffering to achieve any given outcome, whether in this world or a world to come. God works with what God has, and does so in a persuasive and non-coercive manner. This approach requires us to get off the Omnibus that colors so much of traditional theodicies, such as the free will and soul-making responses. With Alyosha, we must confess, "No, not even one".

49 Keller, On the mystery, 48.

50 Griffin, Panentheism and Scientific Naturalism, 82-83.

51 Ford, The lure of God, 12. 
This essay started in affirming the importance that discussions regarding theodicy do not remain abstractions, but address the concrete reality of suffering and evil. At some point in one's life, each person will come face to face with evil, or at least the reality of suffering. Unlike Lewis, we needn't wait for this to happen to adjust our thinking, but can begin to think differently before tragedy strikes. Those who are from the Christian tradition, and for whom belief in God is important, we should not accept the easy answers that the free will response seeks to offer up. We further needn't accept proposals such as Hick's that maintain, if not aggravate, problems associated with the free will defense such as omnipotence. Process theodicy enables one to think afresh the nature of God and the reality of suffering in one's life. In requires us to get off the omnibus and embrace a God whose power is persuasive and not coercive. It requires us to get off the omnibus and embrace a God for whom the future is open, who moves with us through each moment and its attended risks.

\section{References}

Augustine, Aurelius. The City of God. New York: Doubleday, 1958.

Augustine, Aurelius. 'Evil as the Privation of Good'. In A. Eshleman, Readings in Philosophy of Religion: East meets West, Blackwell Publishing, Carlton, 2008, 278-279.

Camus, Albert, The Rebel. Penguin: Middlesex, 1974.

Dostoyevsky, Foydor. The Brothers Karamazov. London: Penguin, 1993.

Dombrowski, Daniel. Whitehead's Religious Thought: from mechanism to organism, from force to persuasion. New York: SUNY Press, 2017.

Dunne, Carl. Carl Jung: Wounded Healer of the soul London: Watkins, 2012.

Evans, C. Stephen and R. Zachary Manis. Philosophy of Religion: thinking about faith. Downers Grove: IVP, 2009.

Lewis, C. S. The problem of Pain. London: Centenary Press, 1940.

Lewis, C. S. A Grief observed. New York: Harper One, 1994.

Griffin, David. Evil Revisited: responses and considerations. New York: SUNY Press, 1991.

Griffin, David. Panentheism and Scientific Naturalism. Claremont: Process Century Press, 2014.

Hartshorne, Charles. Omnipotence and other theological mistakes. New York: SUNY Press, 1984.

Hick, John. Evil and the God of Love. Norfolk: Collins, 1975.

Hick, John. “Transcendence and truth”". In D.Z. Phillips \& T. Tessin (eds), Religion without transcendence?, London, MacMillan, 1997.

Hick, John. Between Faith and Doubt: Dialogues on Religion and Reason. New York: Palgrave, 2010.

Hume, David. Dialogues concerning natural religion. United States: Hackett, 1998.

Jonas, Hans. "The Concept of God after Auschwitz: A Jewish voice” In The Journal of Religion 67:1, 1-13, 1987.

Jung, Carl. Answer to Job. New York: Bollingen, 1958.

Kaufman, Whitley. “Karma, Rebirth, and the Problem of Evil”. In Philosophy East \& West 59:1, 15-32, 2005.

Keller, Catherine. On the mystery: Discerning Divinity in Process. Minneapolis: Fortress, 2008.

Mackie, John. "Evil and omnipotence." Mind 64 (1954), 200-212.

Matilal, Bimal. "Samkara’s theodicy”. Journal of Indian Philosophy 20 (1992), 363-376.

McCord Adams, Marilyn. Horrendous Evils and the Goodness of God. Ithaca: Cornell University Press, 2000.

Rowe, William. "The evidential problem of evil”. In Philosophy of Religion: an introduction edited by William Rowe, 98-110, 2001.

Swinburne, Richard. “God”. In Philosophy of religion: an anthology, edited by C Taliaferro, P.J Griffiths, Malden: Blackwell publishing, 51-57, 2003.

Trakakis, Nick. “Theodicy: The solution to the Problem of Evil, or Part of the Problem?”. Sophia 47 (2008), 161-191.

Van Inwagen, Peter. "The Problem of Evil”. In The Oxford Handbook of Philosophy of Religion, edited by W J Wainwright, 1-15, 2005.

Weisel, Ellie. Night. London: Penguin, 1985. 